\title{
Serum-Mediated Modification of Proliferation in Factor-Dependent Macrophage Cell Lines
}

\author{
Kazunori Ohki* and Osamu Kohashi \\ Department of Microbiology, Saga Medical School, 5-1-1 Nabeshima, Saga 849, Japan
}

Key words: macrophages/cell line/proliferation/serum/LPS

\begin{abstract}
Previously we described that bacterial lipopolysaccharide (LPS) promoted DNA synthesis and supported the cell viability in the factor-dependent macrophage cell lines BDM-1 and BDM-1W3 in the absence of colony-stimulating factor (CSF). To further examine this phenomenon, in the present study we examined the effects of serum on CSF-dependent proliferation and LPS-induced DNA synthesis in BDM-1 and BDM-1W3 cells. Fetal calf serum (FCS) was required for CSF-dependent proliferation in BDM-1 and BDM-1W3 cells. FCS was also required for LPS-induced DNA synthesis in BDM-1W3 cells.

However, at concentrations higher than $0.2 \%$, FCS inhibited LPS-induced DNA synthesis in BDM-1W3 cells in a dose-dependent manner. To obtain the inhibitory activity in FCS (FCS-In) for LPS-induced DNA synthesis, FCS was fractionated by gel filtration chromatography using Sephacryl S-200, chromatography on DEAESephacel, and affinity chromatography on heparin-Sepharose. FCS-In was eluted in the void volume peak from a Sephacryl S-200 column, indicating that FCS-In has a molecular weight of more than 250,000. The molecular weight of FCS-In was apparently 270,000 as determined by SDS-polyacrylamide gel electrophoresis (PAGE) under non-reducing conditions. Upon reduction, four components became detectable with apparent molecular weights of $170,000,110,000,67,000$, and 30,000 . The inhibitory activity in FCS-In material was inactivated by heat and trypsin treatment. The partially purified FCS-In inhibited LPS-induced DNA synthesis in BDM-1W3 cells, but did not inhibit the proliferation of BDM-1W3 cells induced by IL-3, granulocyte-macrophage CSF (GM-CSF), or macrophage CSF (M-CSF).

These results indicate that the inhibition by FCS-In is specific to LPS. Although the site and mechanism of inhibition are not known, FCS-In may function in vivo by modulating the interaction of LPS with macrophages.
\end{abstract}

Macrophages differentiated from progenitor cells may proliferate in vivo under specific circumstances $(18,26)$. Macrophages also proliferate in vitro in the presence of IL-3, GM-CSF, or M-CSF $(5,7)$. When macrophages are cultured in vitro, serum is usually added to the culture medium. However, the role of serum on the growth of macrophages has not been elucidated well as yet. It has been reported that murine bone-marrow-derived macrophage cultures do not depend on the presence of serum-derived growth factors and that the addition of M-CSF as a single factor promoted the growth of virtually pure macrophage cultures (20). In contrast

\footnotetext{
* To whom reprint requests should be addressed.

Abbreviations: BSA, bovine serum albumin; CSF, colony-stimulating factor; FCS, fetal calf serum; FCS-In, inhibitory activity in fetal calf serum; GM-CSF, granulocyte-macrophage CSF; IL-3, interleukin 3; LCM, L-cell conditioned medium; LPS, bacterial lipopolysaccharide; M-CSF, macrophage-CSF; M5A, McCoy's 5A; PAGE, polyacrylamide gel electrophoresis; PBS, Dulbecco's phosphate-buffered saline $\left(\mathrm{Ca}^{++}, \mathrm{Mg}^{++}\right.$free); WEHI3CM, WEHI-3-cell conditioned medium.
}

to these results, the requirement of serum factors for the in vitro growth of mouse (30) and ovine (6) macrophages has been reported.

We previously reported the isolation of three factordependent macrophage cell lines from bone marrow cells of $\mathrm{C} 3 \mathrm{H} / \mathrm{HeN}$ mice (15). We have since isolated a subclone, BDM-1W3, from one of these factor-dependent macrophage cell lines $(16,17)$. In order to gain a better understanding of the serum requirement for macrophage proliferation, we examined the effects of serum on the growth of BDM-1W3 and of its parental cell line, BDM-1.

Bacterial lipopolysaccharide (LPS) is known to affect various functions of macrophages (1). LPS shows inhibitory effects on the proliferation of macrophages in the presence of CSF $(12,17,25)$, whereas it enhances survival of mouse bone-marrow-derived macrophages (25) and human blood monocytes $(2,10)$ in the absence of CSFs. We previously reported that LPS promotes DNA synthesis and supports the cell viability in the absence of CSFs in BDM-1 and BDM-1W3 cells (17). Although 
the molecular mechanisms by which LPS induces DNA synthesis and supports the cell viability in BDM-1 and BDM-1W3 cells have not been elucidated, it is possible that the LPS-induced DNA synthesis and cell survival are mediated by autocrine production of the growth factors. Therefore, whether or not LPS-induced DNA synthesis in BDM-1W3 cells also requires serum is interesting. Therefore we examined the effects of serum on LPS-induced DNA synthesis in BDM-1W3 cells.

We report here, serum requirement for CSF-induced proliferation in BDM-1 and BDM-1W3 cells. Serum was also required for LPS-induced DNA synthesis in BDM-1W3 cells. At high concentrations of FCS, however, the inhibition of LPS-induced DNA synthesis was observed in BDM-1W3 cells. We partially purified and characterized the inhibitory activity in FCS (FCS-In) for LPS-induced DNA synthesis.

\section{MATERIALS AND METHODS}

Cells. The isolation and characterization of two factor-dependent macrophage cell lines, BDM-1 and its subclone, BDM-1W3, have been reported $(15,16,17)$. Conditioned media from L929 cells (LCM) and WEHI-3 cells (WEHI3CM) were prepared as described (14). As previously reported (17), BDM-1 cells respond to M-CSF and BDM-1W3 cells respond to IL-3, GM-CSF, and M-CSF. Since LCM and WEHI3CM are potent sources of M-CSF and IL-3, respectively, BDM-1 and BDM-1W3 cells were cultured in McCoy's 5A (M5A) medium with $20 \%$ fetal calf serum (FCS, Hyclone) containing 50\% LCM and 50\% WEHI3CM, respectively. Calf and horse serum were obtained from Gibco Laboratories [Grand Island, NY].

Reagents. LPS from Salmonella typhi was purchased from Difco (Detroit, MI). Mouse recombinant GM-CSF was obtained from Genzyme (Boston, MA). Mouse recombinant IL-3 was provided by Dr. R. Fukunaga (Osaka Bioscience Institute, Osaka, Japan). Human recombinant M-CSF was donated by Dr. M. Takahashi (Otsuka Pharmaceutical Co., Ltd., Tokushima, Japan).

Cell proliferation assay. The cells were extensively washed with M5A medium, trypsinized, plated in each well at $1 \times 10^{4}$ cells/well in M5A medium with $20 \%$ FCS in the presence or absence of CSFs and incubated for $72 \mathrm{hrs}$ at $37^{\circ} \mathrm{C}$. To measure LPS-induced DNA synthesis, we washed BDM-1W3 cells, trypsinized them, and plated them in each well at $1 \times 10^{4}$ cells/well in the presence or absence of LPS $(10 \mu \mathrm{g} / \mathrm{ml})$ and incubated them for $72 \mathrm{hrs}$ at $37^{\circ} \mathrm{C}$. The cells were pulse-labeled with $1 \mu \mathrm{Ci}$ of $\left[{ }^{3} \mathrm{H}\right]$-thymidine (S, A, $5 \mathrm{Ci} / \mathrm{ml}$, Amersham International plc, England) for the final $48 \mathrm{hrs}$ of culture. Cell proliferation was determined by measuring $\left[{ }^{3} \mathrm{H}\right]$-thymidine incorporation as described before (17).

Gel filtration. Sera $(20 \mathrm{ml})$ were loaded onto a Sephacryl S-200 HR (Pharmacia, Uppsala, Sweden) column $(2 \times 9 \mathrm{~cm})$ and eluted with $10 \mathrm{mM}$ Tris-HCl (pH 7.5) buffer containing
$0.15 \mathrm{M} \mathrm{NaCl}$ at a flow rate of $14 \mathrm{ml} / \mathrm{hr}$; then fractions $(7 \mathrm{ml}$ each) were collected. A sample $(10 \mu \mathrm{l})$ of each fraction was taken and assayed for the inhibitory activity. To determine the inhibitory activity, we cultured BDM-1W3 cells in M5A medium with $0.2 \%$ FCS in the presence of LPS $(10 \mu \mathrm{g} / \mathrm{ml})$ and a sample of each fraction; then cell proliferation was measured by $\left[{ }^{3} \mathrm{H}\right]$-thymidine incorporation as described above. The inhibition of proliferation by the inhibitory factor was calculated relative to the response of cultures without the inhibitory factor.

DEAE-Sephacel chromatography. The fraction containing the inhibitory activity, which was eluted at void volume from a Sephacryl S200 column, was pooled, concentrated by ultrafiltration (Diaflo YM10, Amicon, Lexington, MA), and dialyzed against phosphate buffer $\left(25 \mathrm{mM} \mathrm{NaH} \mathrm{NO}_{4} /\right.$ $\left.\mathrm{Na}_{2} \mathrm{HPO}_{4}, \mathrm{pH} 6.0\right)$. A column $(2 \times 12 \mathrm{~cm})$ of DEAE-Sephacel (Pharmacia, Uppsala, Sweden) was equilibrated with the same buffer. The sample $(8 \mathrm{ml})$ was applied to the column and eluted stepwise with $100 \mathrm{ml}$ of phosphate buffer, $100 \mathrm{ml}$ of $0.1 \mathrm{M} \mathrm{NaCl}$ in phosphate buffer, and $100 \mathrm{ml}$ of $1.5 \mathrm{M} \mathrm{NaCl}$ in phosphate buffer. Seven-milliliter fractions were collected and assayed for the inhibitory activity. For the next purification step, fractions containing the inhibitory activity were combined, concentrated, and dialyzed against $0.1 \mathrm{M} \mathrm{NaCl}$ in 25 $\mathrm{mM} \mathrm{NaH} \mathrm{PO}_{4} / \mathrm{Na}_{2} \mathrm{HPO}_{4}(\mathrm{Na} / \mathrm{Pi})$ at $\mathrm{pH} 6.5$.

Heparin-Sepharose chromatography. A column $(1.5 \times$ $4.0 \mathrm{~cm}$ ) of heparin-Sepharose CL-6B (Pharmacia, Uppsala, Sweden) was previously equilibrated with $0.1 \mathrm{M} \mathrm{NaCl}$ in 25 $\mathrm{mM} \mathrm{Na} / \mathrm{Pi}(\mathrm{pH} 6.5)$. The sample $(5 \mathrm{ml})$ from the previous step was applied to the column and eluted stepwise with 100 $\mathrm{ml}$ of $0.1 \mathrm{M} \mathrm{NaCl}$ in $25 \mathrm{mM} \mathrm{Na} / \mathrm{Pi}(\mathrm{pH} 6.5$ ), $70 \mathrm{ml}$ of $0.1 \mathrm{M}$ $\mathrm{NaCl}$ in $50 \mathrm{mM} \mathrm{Na} / \mathrm{Pi}(\mathrm{pH} \mathrm{7.5}$ ), and finally $70 \mathrm{ml}$ of $1.5 \mathrm{M}$ $\mathrm{NaCl}$ in $50 \mathrm{mM} \mathrm{Na} / \mathrm{Pi}$ (pH 7.5). Fractions containing the inhibitory activity were pooled, concentrated, and dialyzed against Dulbecco's $\mathrm{Ca}^{++}, \mathrm{Mg}^{++}$-free phosphate-buffered saline (PBS).

Polyacrylamide gel electrophoresis (PAGE). Fractions containing the inhibitory activity, which eluted at the breakthrough volume from the heparin-Sepharose column, were pooled and concentrated. SDS-PAGE was performed with 4$20 \%$ gradient gels. The buffer system of Laemmli (9) was used. The molecular weight was determined by comparison of the mobility with that of standard proteins (molecular weights in parentheses): myosin $(212,000), \alpha_{2}$-macroglobulin $(170,000)$, $\beta$-galactosidase $(116,000)$, transferrin $(76,000)$, glutamic dehydrogenase $(53,000)$, and carbonic anhydrase $(30,000)$.

Characterization of inhibitory activity. Experiments designed to determine if the FCS-In preparation was inactivated by incubation with trypsin were carried out by use of trypsin covalently bound to acrylic beads (Sigma Chemical Co., St. Louis, Mo). Approximately $57 \mu \mathrm{g}$ of the partially purified FCS-In preparation was incubated overnight at room temperature in $0.3 \mathrm{ml}$ of PBS containing 13 units of trypsin. In the control experiment, the same amount of FCS-In was incubated in the same manner in PBS without trypsinbeads. In 
another control experiment, trypsinbeads were incubated in PBS without the FCS-In material and removed by centrifugation; then the supernatant was assayed for inhibitory activity. The inhibitory activity toward LPS-induced DNA synthesis in aliquots of this incubation mixture was assayed as described.

\section{RESULTS}

Effects of serum on CSF-induced DNA synthesis of macrophage cell lines. We previously reported that BDM-1 cells responded to M-CSF, and BDM-1W3 cells to M-CSF, GM-CSF, and IL-3, with proliferation (17). To examine the effects of serum on the DNA synthesis in BDM-1 and BDM-1W3 cells, we cultured the cells with CSFs and various concentrations of FCS. When the FCS concentration was raised from $0.2 \%$ to $25 \%$, CSF-dependent DNA synthesis in both cell lines was enhanced in a dose-dependent manner (Fig. 1), indicating that CSF-induced DNA synthesis in these cells depends on the presence of serum. The same requirement was also observed with BDM-1 and BDM-1W3 cells cultured with various concentrations of M-CSF and IL-3, respectively (data not shown).

Effects of serum on cell growth. We then examined the effects of serum on M-CSF-induced cell growth. BDM-1 and BDM-1W3 cells were cultured with 990 units/ml of human recombinant $\mathrm{M}$-CSF in the presence of various concentrations of FCS. When BDM- 1 cells were cultured with $0.2 \% \mathrm{FCS}$, the cells died gradually (Fig. 2a). At 10\% and 25\% serum, the cells grew rapidly, and the total cell number increased approximately 17-to-20-fold by day 12 of culture. In contrast to BDM1 cells, BDM-1W3 cells did not die in $0.2 \%$ serum although they did not grow (Fig. 2b), suggesting that serum requirement of BDM-1W3 cells is low compared with that of BDM-1 cells. These results confirm that CSF-dependent cell proliferation in BDM-1 and BDM$1 \mathrm{~W} 3$ cells requires serum.

Effects of serum on LPS-induced DNA synthesis in $B D M-1 W 3$ cells. As previously reported (17), LPS induced the incorporation of $\left[{ }^{3} \mathrm{H}\right]$-thymidine into BDM1W3 cells in the absence of CSFs. To examine the effects of serum on LPS-induced DNA synthesis, we cultured BDM-1W3 cells with LPS in the presence of various concentrations of FCS. As shown in Fig. 3, LPS-induced DNA synthesis was not observed when cells were incubated in the absence of FCS, showing that LPS-induced DNA synthesis also requires serum. However, in contrast to CSF-dependent cell proliferation, high concentrations of serum inhibited LPS-induced DNA synthesis. At $25 \%$ of FCS, an approximately $70 \%$ reduction was observed. Similar inhibition was observed with another lot of FCS (data not shown). We examined whether high concentrations of calf serum or horse serum affected LPS-induced DNA synthesis (Fig. 3). The amount of $\left[{ }^{3} \mathrm{H}\right]$-thymidine incorporated into the cells cultured with calf or horse serum was low compared with that of the cells cultured with FCS, and no significant inhibition of LPS-induced DNA synthesis was observed with either of these sera.

Purification and characterization of inhibitory activity. To gain more information about the inhibitory
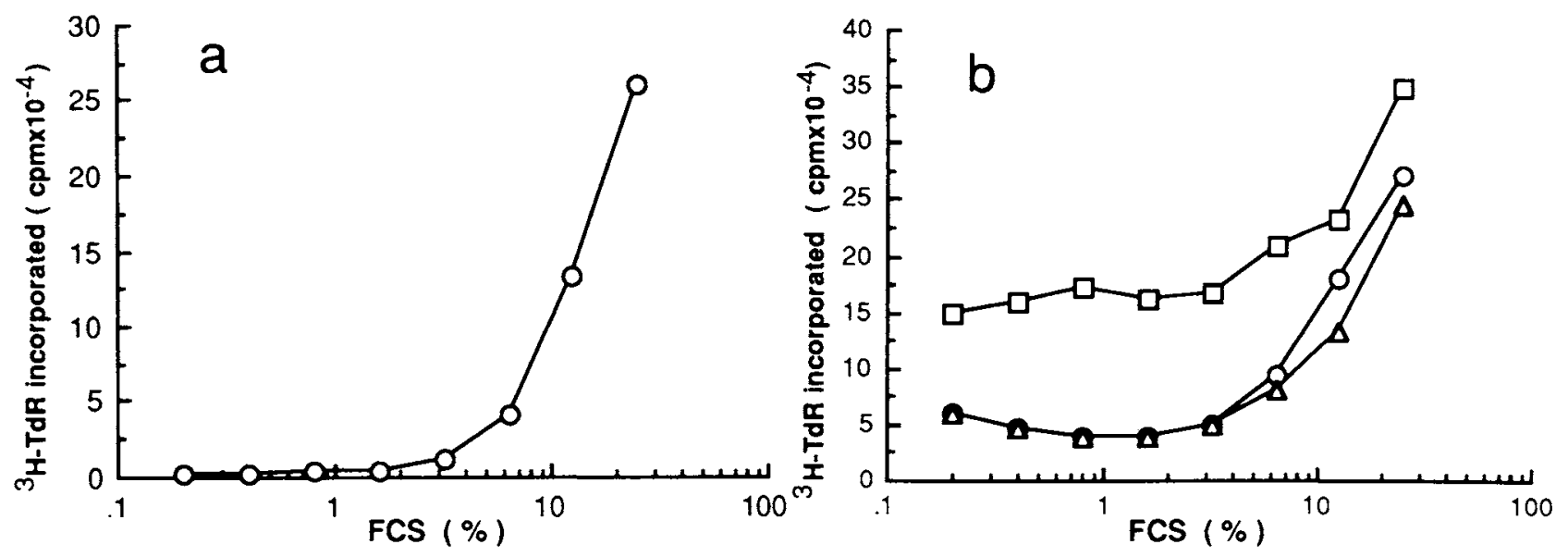

Fig. 1. Effects of serum on CSF-dependent DNA synthesis in BDM-1 and BDM-1W3 cells.

(a): BDM-1 cells were cultured for $72 \mathrm{hrs}$ in M5A medium containing human recombinant M-CSF $(2,250 \mathrm{U} / \mathrm{ml})$ and various concentrations of FCS (O). (b): BDM-1W3 cells were cultured for $72 \mathrm{hrs}$ in M5A medium containing human recombinant M-CSF $(9,000 \mathrm{U} / \mathrm{ml})(O)$, mouse recombinant GM-CSF $(100 \mathrm{U} / \mathrm{ml})(\triangle)$, or mouse recombinant IL-3 $(800 \mathrm{U} / \mathrm{ml})(\square)$ and various concentrations of FCS.

DNA synthesis was measured as described in Materials and Methods. The mean values for $\left[{ }^{3} \mathrm{H}\right]$-thymidine incorporation (cpm/well) in the absence of M-CSF at 25\% FCS were 2,171 and 3,309 for BDM-1 and BDM-1W3 cells, respectively. Results represent the average of duplicate determinations. 

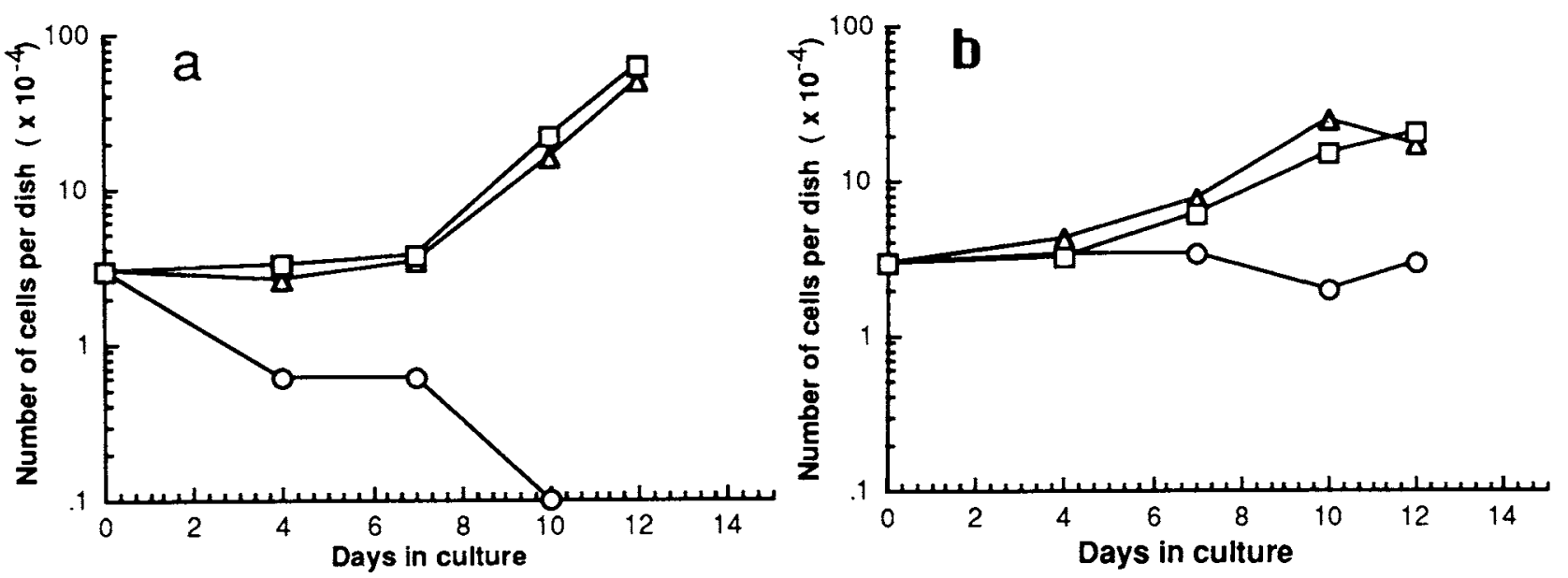

Fig. 2. Effects of serum on M-CSF-dependent cell growth.

BDM-1 (a) and BDM-1W3 (b) cells were plated in M5A medium containing $0.2 \%(0), 10 \%(\triangle)$, or $25 \%(\square)$ FCS in the presence of M-CSF $(1,000 \mu / \mathrm{ml})$ at $3 \times 10^{4}$ cells $/ 35-\mathrm{mm}$ dish. At the times indicated, the cells were trypsinized, and the number of cells was counted with a hemocytometer. Results are expressed as the mean of duplicate cultures.

effects of FCS on LPS-induced DNA synthesis, we partially purified the fraction containing inhibitory activity using gel filtration, ion-exchange chromatography and affinity chromatography. At first, FCS was chromatographed on a Sephacryl S-200 HR column, and various fractions were assayed for the inhibition of LPS-induced DNA synthesis in BDM-1W3 cells cultured with $0.2 \%$ FCS. When FCS was applied to the column, a major peak containing the inhibitory activity was eluted

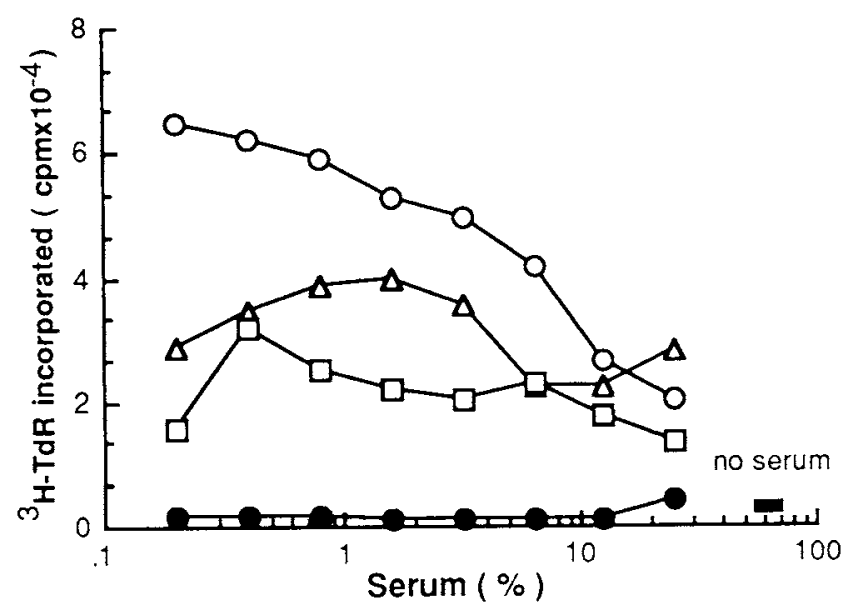

Fig. 3. Effects of serum on LPS-induced DNA synthesis in BDM1W 3 cells. Cells were incubated for $72 \mathrm{hrs}$ in M5A medium containing various concentrations of FCS $(O)$, calf serum $(\triangle)$, or horse serum ( $\square$ ) in the presence of LPS $(10 \mu \mathrm{g} / \mathrm{ml})$. In the control culture, the cells were plated in M5A medium with various concentrations of FCS in the absence of LPS $(\bullet)$. Results represent the average of duplicate determinations.

The mean $\left[{ }^{3} \mathrm{H}\right]$-thymidine incorporation ( $\mathrm{cpm} /$ well) was 2,446 for the cells cultured with LPS $(10 \mu \mathrm{g} / \mathrm{ml})$ in the absence of FCS $(\square)$. from the column in the void volume peak (Fig. 4). Since the upper fractionation limit of Sephacryl S-200 HR has an approximate molecular weight of 250,000 , the inhibitory activity has a molecular weight of more than this

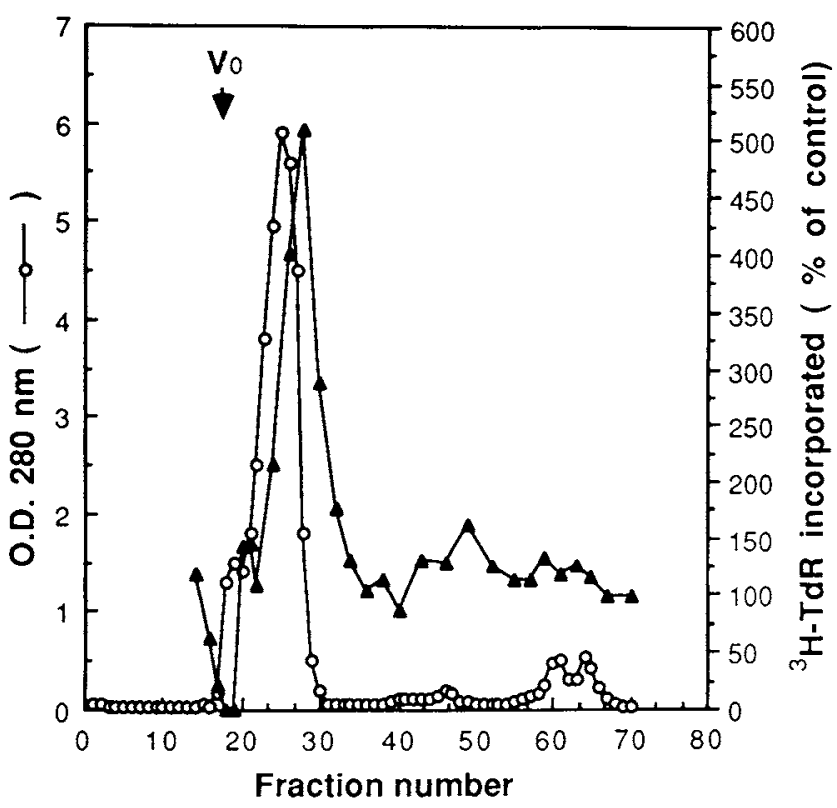

Fig. 4. Gel filtration of FCS. The chromatography conditions and column size were described in Materials and Methods. Seven-milliliter fractions were collected, and elution of protein was measured by absorption at $280 \mathrm{~nm}(0)$. A sample from each fraction was assayed in duplicate for the inhibitory activity $(\Delta)$. The mean $\left[{ }^{3} \mathrm{H}\right]$-thymidine incorporation (cpm/well) was 6,371 for the cells cultured with LPS (10 $\mu \mathrm{g} / \mathrm{ml}$ ) only. The column was calibrated with BSA (MW 67,000) and $\alpha$-chymotrypsinogen (MW 25,000). BSA and $\alpha$-chymotrypsinogen eluted from the column at fraction numbers 22 and 31 , respectively. 
value. Gel filtration of lipoprotein-depleted FCS also revealed a major peak of the inhibitory activity in the void volume peak (data not shown). These results suggest that the inhibitory activity is not contained in the lipoprotein fraction in serum. Next, the fraction containing inhibitory activity from gel filtration was passed through a DEAE-Sephacel column. The active fraction was eluted showing a distinct peak at $1.5 \mathrm{M} \mathrm{NaCl}$ in phosphate buffer (Fig. 5). We further purified the inhibitory activity using a heparin-Sepharose column. One major peak of the inhibitory activity appeared in the breakthrough volume and two minor peaks were eluted at $0.1 \mathrm{M} \mathrm{NaCl}$ and $1.5 \mathrm{M} \mathrm{NaCl}$ in phosphate buffer (Fig. 6). The active fraction indicated by the major peak was pooled, concentrated and dialyzed; its properties were then characterized. The material that eluted as the major peak from the heparin-Sepharose column was subjected to SDS-PAGE (Fig. 7). When not reduced, the material consisted of two proteins, which migrated in a major band with an apparent molecular weight of 270,000 and the other, in a minor band with a molecular weight of 320,000 (lane 1). Upon reduction, four components became detectable with apparent molecular weights of $170,000,110,000,67,000$, and 30,000 (lane 2). When the partially purified inhibitory factor

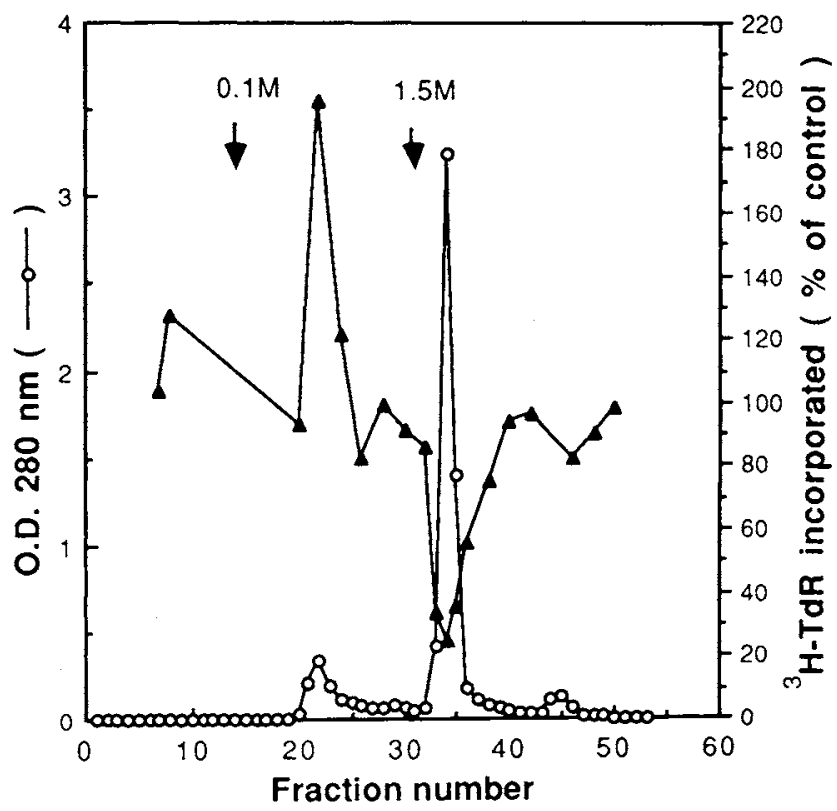

Fig. 5. DEAE-Sephacel chromatography. The active material from the gel filtration chromatographic step was processed as described in Materials and Methods, and $8 \mathrm{ml}$ of sample was loaded on a DEAESephacel column. Elution of protein was monitored by absorption at $280 \mathrm{~nm}(0)$, and an aliquot $(10 \mu \mathrm{l})$ of each fraction was assayed for the inhibitory activity $(\boldsymbol{\Lambda})$. The results are expressed as the mean of triplicate determinations. The mean $\left[{ }^{3} \mathrm{H}\right]$-thymidine incorporation (cpm/well) was 14,733 for the cells cultured with LPS $(10 \mu \mathrm{g} / \mathrm{ml})$ only. from FCS (FCS-In) was incubated at $56^{\circ} \mathrm{C}$ for $30 \mathrm{~min}$, or at $100^{\circ} \mathrm{C}$ for $5 \mathrm{~min}$, the inhibitory activity was reduced, although it was not completely lost (Fig. 8). The inhibitory activity in the FCS-In material was also partially reduced upon incubation with trypsin (Fig. 8).

Effects of FCS-In on DNA synthesis of BDM-1W3 cells. The FCS-In did not inhibit M-CSF-, GM-CSF-, and IL-3-dependent cell proliferation in BDM-1W3 cells (Fig. 9a). Interestingly, FCS-In stimulated M-CSFand GM-CSF-induced proliferation in these cells. At $10 \mu \mathrm{g} / \mathrm{ml}$, the stimulation in M-CSF-dependent BDM1W3 cell proliferation was about $100 \%$. These stimulatory effects of FCS-In were not observed with IL-3-dependent $\mathrm{BDM}-1 \mathrm{~W} 3$ cell proliferation. It is not clear whether the stimulation of M-CSF- or GM-CSF-dependent BDM-1W3 cell proliferation is due to the presence of distinct substances in FCS-In preparation. At $10 \mu \mathrm{g}$ $/ \mathrm{ml}$, bovine serum albumin (BSA) and $\alpha_{2}$-macroglobulin did not stimulate M-CSF-dependent BDM-1W3 cell proliferation (data not shown).

FCS-In also did not inhibit M-CSF-dependent cell proliferation in BDM-1 cells (data not shown). In contrast, FCS-In inhibited LPS-induced DNA synthesis in BDM-1W3 cells dose-dependently (Fig. 9b). At $1 \mu \mathrm{g}$ $/ \mathrm{ml}$, approximately $40 \%$ reduction was observed; and

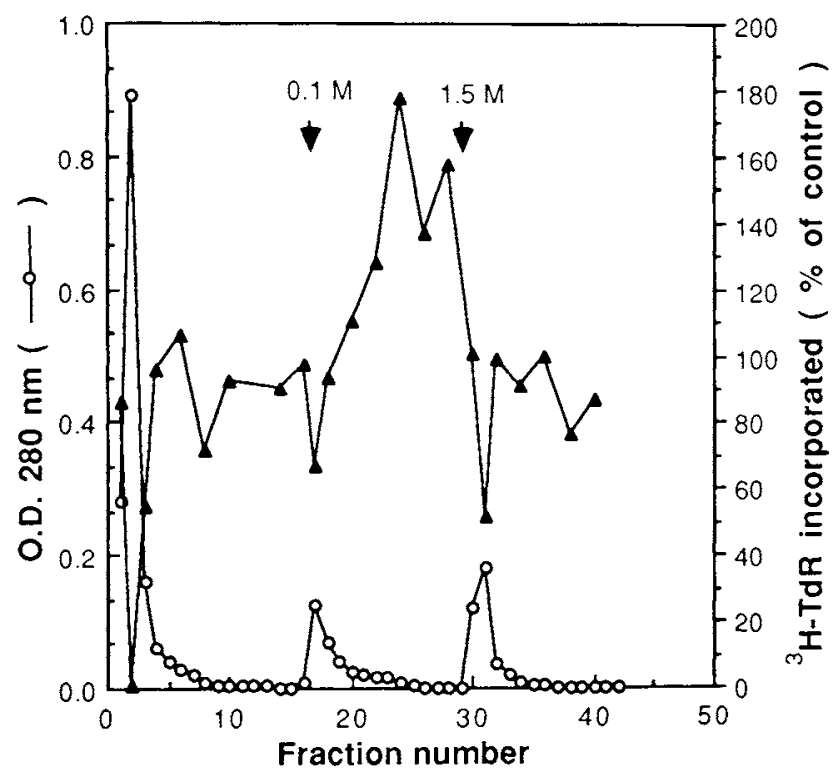

Fig. 6. Heparin-Sepharose column chromatography. Active fractions from the DEAE-Sephacel column were pooled and processed as described in Materials and Methods. A $5 \mathrm{ml}$ sample was then loaded onto a heparin-Sepharose column, the column eluted with $\mathrm{NaCl}(0-$ $1.5 \mathrm{M}$ ) in phosphate buffer in a stepwise manner, and 7-milliliter fractions were collected. Protein elution patterns were monitored by absorbance reading at $280 \mathrm{~nm}(O)$. Each fraction was assayed in triplicate for the inhibitory activity at a final concentration of $10 \%(\mathrm{v} / \mathrm{v})$ ( $)$. The mean $\left[{ }^{3} \mathrm{H}\right]$-thymidine incorporation in the control cultures containing LPS only was 10,058 (cpm/well). 


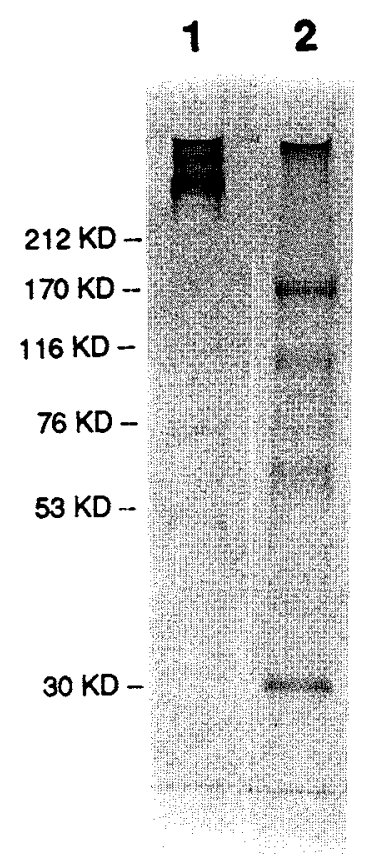

Fig. 7. SDS-polyacrylamide gradient (4-20\%) slab gel electrophoresis. FCS-In eluted from the heparin-Sepharose column was analyzed before (lane 1) and after (lane 2) reduction of disulfide bridges with $5 \% \beta$-mercaptoethanol at $100^{\circ} \mathrm{C}$ for $5 \mathrm{~min}$. Five micrograms of protein was applied per lane. The positions of molecular weight standard proteins are indicated at the left.

at $10 \mu \mathrm{g} / \mathrm{ml}$, DNA synthesis was reduced to about $20 \%$ of the control value.

Effects of FCS-In on survival of BDM-IW3 cells. We then examined the effects of FCS-In on LPS-induced cell survival of BDM-1W3 cells. BDM-1W3 cells were incubated with $10 \mu \mathrm{g} / \mathrm{ml}$ of LPS in the presence or absence of FCS-In or with FCS-In only for 6 days. When the cells were incubated with FCS-In in the absence of LPS, no inhibition was observed with respect to the control value. However, the LPS-induced cell survival was inhibited by FCS-In (Fig. 10).

\section{DISCUSSION}

The present study demonstrated that serum was required for CSF-induced proliferation in the factor-dependent macrophage cell lines BDM-1 and BDM-1W3. The requirements of serum factors present in FCS for the proliferation of macrophages $(6,30)$ and a factor-dependent hemopoietic cell line (4) have been reported previously. However, the precise nature of these serum factors has not been well defined as yet.

We previously reported that LPS promotes DNA synthesis and supports cell viability in the absence of CSFs in BDM-1 and BDM-1W3 cells (17). It has been unclear whether LPS works directly on BDM-1 and BDM-1W3

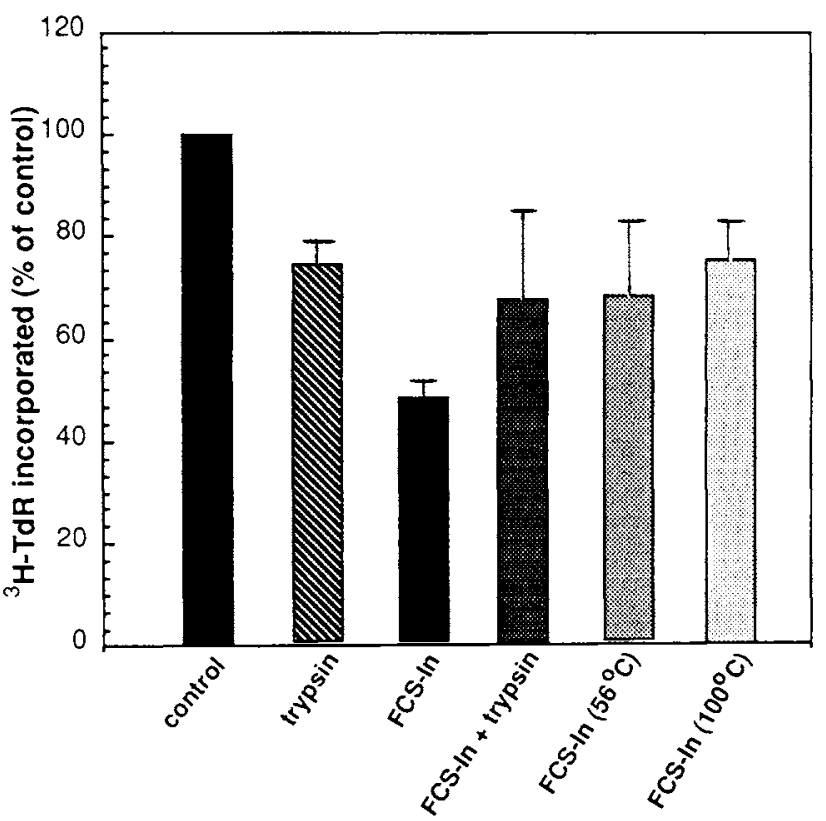

Fig. 8. Sensitivity of FCS-In to heat and trypsin. The FCS-In material purified by chromatography on the heparin-Sepharose column was treated with trypsin as described in Materials and Methods. Another sample of FCS-In material was incubated at $65^{\circ} \mathrm{C}$ for $30 \mathrm{~min}$ or at $100^{\circ} \mathrm{C}$ for $5 \mathrm{~min}$. BDM-1W3 cells were plated in M5A medium with $0.2 \%$ FCS in the presence of LPS $(10 \mu \mathrm{g} / \mathrm{ml})$ and FCS-In $(60 \mu \mathrm{g}$ $/ \mathrm{ml})$, heat- or trypsin-treated FCS-In $(60 \mu \mathrm{g} / \mathrm{ml})$, or supernatant of trypsin bead-treated PBS at $1 \times 10^{-4}$ cells/well and incubated for 72 hrs. DNA synthesis was measured as described in Materials and Methods. The mean $\left[{ }^{3} \mathrm{H}\right]$-thymidine incorporation (cpm/well) in the cells cultured with LPS $(10 \mu \mathrm{g} / \mathrm{ml})$ in the absence of FCS-In was 21,822 . Results are expressed as the mean of triplicate cultures ( \pm S.D.).

cells or whether promotion by LPS is mediated by an autocrine production of the mediators. If LPS-induced DNA synthesis was mediated by an autocrine production of the growth factors, LPS-stimulated BDM-1W3 cells might require the serum factor as observed with CSF-stimulated cells. Although a low concentration of FCS was required, high concentrations of FCS inhibited LPS-induced DNA synthesis in BDM-1W3 cells (Fig. 3). In comparison with FCS, calf serum and horse serum did not show significant inhibitory activity toward LPS-induced DNA synthesis in BDM-1W3 cells. These results suggest that an abundant amount of the inhibitory activity responsible for the inhibition of LPSinduced DNA synthesis is contained specifically in FCS. Since a mouse bone-marrow-derived macrophage cell line has been used for the assay of DNA synthesis, these results indicate a lack of species specificity for the inhibitory activity of the molecules. The inhibition of LPS-induced splenic B cell activation by normal mouse serum was previously reported (28). The inhibition of the biological activity of LPS by human (8) and normal rabbit serum (22) was also reported. 

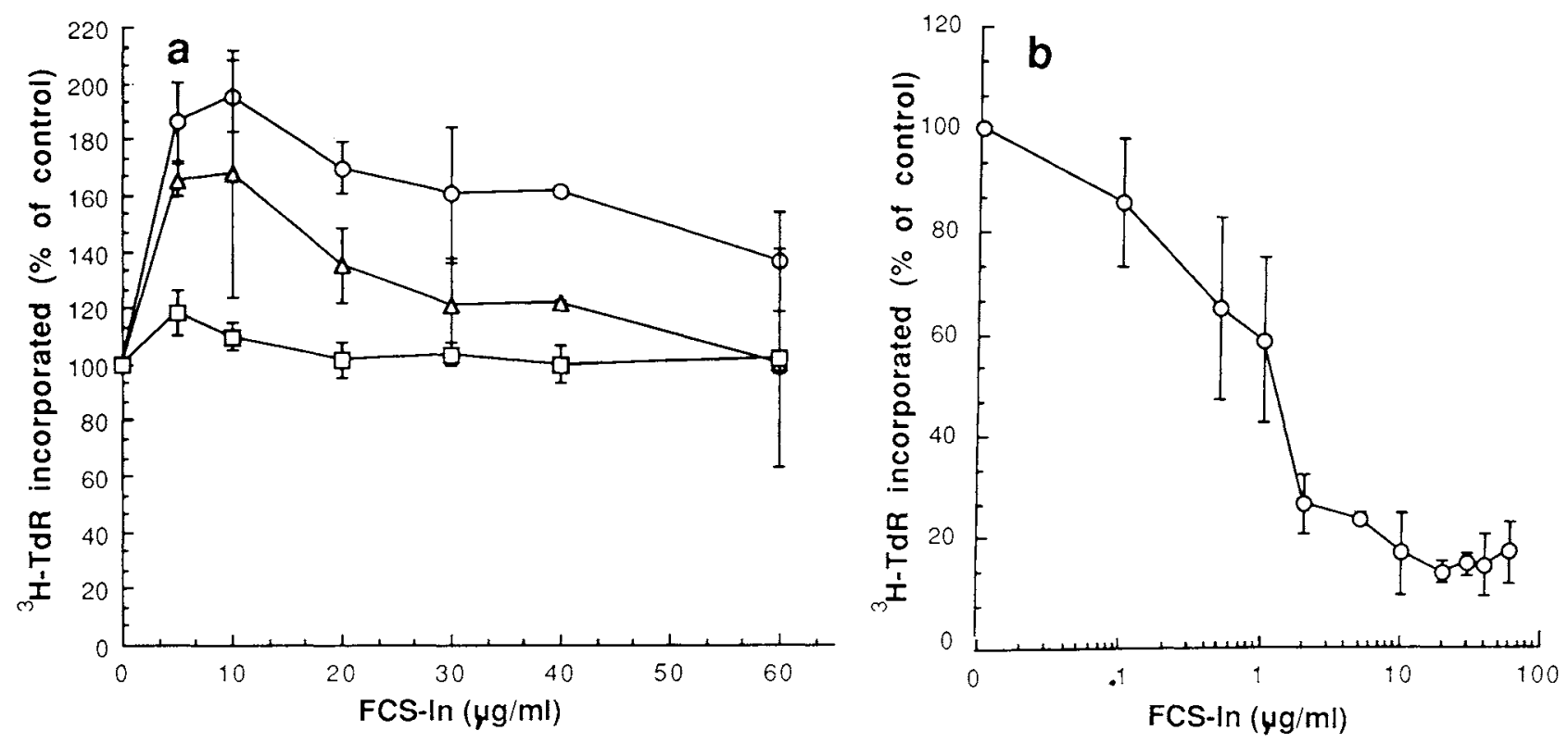

Fig. 9. Effects of FCS-In on proliferation of BDM-1W3 cells.

(a): BDM-1W3 cells were cultured for $72 \mathrm{hrs}$ in M5A medium containing $0.2 \%$ FCS with M-CSF $(12,000 \mathrm{U} / \mathrm{ml})(O), \mathrm{GM}-\mathrm{CSF}(575 \mathrm{U} / \mathrm{ml})(\triangle)$, or IL-3 $(400 \mathrm{U} / \mathrm{ml})(\square)$ in the presence of various concentrations of FCS-In. The mean values of $\left[{ }^{3} \mathrm{H}\right]$-thymidine incorporation were $15,093,37,251$, and 88,770 for BDM-1W3 cells cultured with M-CSF, GM-CSF, and IL-3, respectively, in the absence of FCS-In. (b): BDM-1W3 cells were cultured for $72 \mathrm{hrs}$ in M5A medium with $0.2 \%$ FCS and LPS $(10 \mu \mathrm{g} / \mathrm{ml})$ in the presence of various concentrations of FCS-In (O). The mean [ $\left.{ }^{3} \mathrm{H}\right]-$ thymidine incorporation (cpm/well) in the absence of FCS-In was 24,365 . Results are expressed as the mean of triplicate determinations ( \pm S.D.).

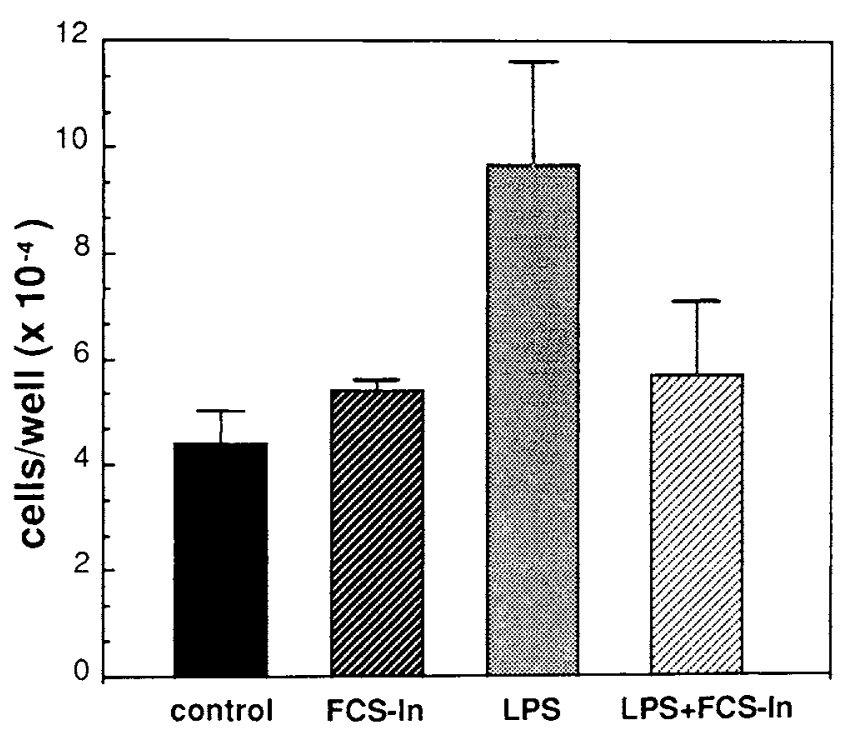

Fig. 10. Effects of FCS-In on LPS-induced cell survival. BDM-1W3 cells were plated in M5A medium with $0.2 \% \mathrm{FCS}$ in the presence or absence of LPS $(10 \mu \mathrm{g} / \mathrm{ml})$ and/or FCS-In $(30 \mu \mathrm{g} / \mathrm{ml})$ at 1 $\times 10^{5} \mathrm{cells} / \mathrm{ml} /$ well. After 6 days of incubation, the cells were trypsinized and the cell number was counted. Results are expressed as the mean of triplicate cultures ( \pm S.D.).
To investigate the properties of the inhibitory activity in FCS, FCS was fractionated by gel filtration on a Sephacryl S-200 column. The inhibitory activity was eluted in the void volume peak containing macromolecules such as $\alpha_{2}$-macroglobulin (Fig. 4). These results indicate that the inhibitory activity has a molecular weight of approximately more than 250,000 . The inhibitory activity was further purified by chromatography on DEAE-Sephacel and heparin-Sepharose columns. When the molecular weight of partially purified inhibitory activity (FCS-In) was estimated by SDS-PAGE, the molecular weight of 270,00 was obtained under non-reducing conditions. Upon reduction, four bands with apparent molecular weights of 170,000, 110,000, 67,000, and 30,000 were detected (Fig. 7). These four proteins were electroblotted onto polyvinylidene diffuoride membranes, and partial $\mathrm{NH}_{2}$-terminal amino acid sequences were determined. When the $\mathrm{NH}_{2}$-terminal sequences of these four proteins were searched for in the Swiss-Prot 19 protein data base, we found that the two proteins having molecular weights of 170,000 and 110,000 were homologous to human $\alpha_{2}$-macroglobulin and a third protein (MW. 67,000) was homologous to BSA. However, no homologous relationship between the protein having the molecular weight of 30,000 and any other proteins that have been already sequenced was shown (K. Ohki, unpublished results). Further bio- 
chemical characterization of this material revealed sensitivity to heat as well as trypsin, demonstrating it to be proteinareous in nature (Fig. 8). FCS-In inhibited LPSinduced DNA synthesis and the promotion of viability in BDM-1W3 cells, whereas it did not affect M-CSF-, GM-CSF-, and IL-3-induced DNA synthesis in the same cells (Fig. 9). These results suggest that FCS-In is a factor specific for LPS rather than a nonspecific cytotoxic factor. The inactivation of LPS in most studies appears to involve interaction of LPS with non-immunoglobulin factors in the serum. It has been reported that LPS interacts with a variety of plasma proteins including transferrin (3) and $\alpha_{2}$-macroglobulin (21). Human $\alpha_{2}$-macroglobulin and BSA did not inhibit LPS-induced DNA synthesis in BDM-1W3 cells (data not shown). In another series of studies, it was shown that LPS binds to high-density lipoproteins in serum and plasma and that the resulting LPS-lipoprotein complex is markedly less active than unbound LPS in many systems $(23,24)$. In addition to high-density lipoproteins, low-density lipoproteins bind LPS and markedly reduce the cytotoxic effects of LPS $(13,27)$. However, in our case FCS-In was purified from lipoprotein-depleted FCS (data not shown). Our preliminary results indicated that partially purified FCS-In inhibited the proliferation of a mouse myelomonocytic leukemic cell line (WEHI3), and induced the expression of Fc-receptor on WEHI3 cells, whereas lipoproteins isolated from FCS did not show these activities (K. Ohki, unpublished results). Therefore, it is unlikely that FCS-In has the same molecular properties as lipoproteins. Recently, it was reported that the complex of LPS and an LPS-binding protein interacts with CD14 or binding sites for LPS on the surface of monocytes and macrophages $(11,19,29)$. Thus, an explanation for the inhibition of LPS-induced DNA synthesis could be that before being attached to the cells, LPS binds to FCS-In and the resulting LPS-FCSIn complex is less active than unbound LPS. An alternative explanation could be that FCS-In itself is a ligand for CD14 and the interaction between these molecules prevents the specific binidng of LPS to the cells. The third possibility is that the interaction of FCS-In with its specific receptor prevents the transduction of signals resulted from the interaction of LPS with the cells. In our preliminary experiments, the partially purified FCSIn inhibited the proliferation of mouse and rat myeloid leukemic cell lines and a mouse macrophage-like cell line. Furthermore, FCS-In enhanced Fc-mediated phagocytosis by a mouse macrophage-like cell line (K. Ohki, unpublished results). Taken together, these results suggest that FCS-In binds to the cells and the intracellular signals are transduced from the interaction of FCS-In with the cells.

Because FCS-In was not completely purified in this study, it is possible that several inhibitory molecules were also detected by the procedure shown here. Further purification of FCS-In is in progress.

Acknowledgments. We thank Drs. R. Fukunaga and S. Nagata for their generous supply of mouse recombinant IL-3, and Dr. M. Takahashi for human recombinant M-CSF.

\section{REFERENCES}

1. Adams, D.O. and Hamilton, T.A. 1984. The cell biology of macrophage activation. Ann. Rev. Immunol., 2: 283-318.

2. Becker, S., Warren, M.K., and Haskill, S. 1987. Colonystimulating factor-induced monocyte survival and differentiation into macrophages in serum-free cultures. J. Immunol., 139: 3703-3709.

3. Berger, D., Schleich, S., Skidelmann, M., and Berger, H.G. 1991. Demonstration of an interaction between transferrin and lipopolysaccharide-An in vitro study. Eur. Surg. Res., 23: 309-316.

4. Bohmer, R.M. 1989. Interaction of serum and colony-stimulating factor for survival of a factor-dependent hemopoietic progenitor cell line. J. Cell. Physiol., 139: 531-537.

5. Chen, B.D.M., Mueller, M., and OlenCKI, T. 1988. Interleukin-3 (IL-3) stimulates the clonal growth of pulmonary alveolar macrophage of the mouse: Role of IL-3 in the regulation of macrophage production outside the bone marrow. Blood, 72: 685690.

6. Francey, T., Jungi, T.W., Rey, O., and Peterhans. 1992. Culture of ovine bone marrow-derived macrophages and evidence for serum factors distinct from M-CSF contributing to their propagation in vitro. J. Leukocyte Biol., 51: 525-534.

7. Hamilton, J.A., Vairo, G., Nicola, N.A., Burgess, A., MetCAlF, D., and LiNGelbaCK, S.R. 1988. Activation and proliferation signals in murine macrophages: Synergistic interactions between the hematopoietic growth factors and with phorbol ester for DNA synthesis. Blood, 71: 1574-1580.

8. Johnson, K.J., Ward, P.A., Gorainick, S., and Osborn, M.J. 1977. Isolation from human serum of an inactivator of bacterial lipopolysaccharide. Am. J. Pathol., 88: 559-574.

9. LAEMMLI, U. 1970. Cleavage of structural proteins during the assembly of the head of bacteriophage. Nature (London), 227: 680-685.

10. MANGAN, D.F., WELCH, G.R., and WAHL, S.M. 1991. Lipopolysaccharide, tumor necrosis factor- $\alpha$, and IL-1 prevent programmed cell death (apoptosis) in human peripheral blood monocytes. J. Immunol., 146: 1541-1546.

11. Mathison, J.C., Tobias, P.S., Wolfson, E., and Ulevitch, R.J. 1992. Plasma lipopolysaccharide (LPS)-binding protein. A key component in macrophage recognition of gram-negative LPS. J. Immunol., 149: 200-206.

12. MoORe, R.N., Steeg, P.S., MaNned, D.N., and MergenhaGen, S.E. 1980. Role of lipopolysaccharide in regulating colony-stimulating factor-dependent macrophage proliferation in vitro. Infect. Immun., 30: 797-804.

13. Navab, M., Hough, G.P., van Lenten, B.J., Berliner, J.A., and Fogelman, A.M. 1988. Low density lipoproteins transfer bacterial lipopolysaccharides acrose endothelial monolayers in a biologically active from. J. Clin. Invest., 81: 601-605.

14. OhKI, K. and Nagayama, A. 1983. Cell hybrids between SV40-transformed macrophage cell lines and a Chinese-hamster cell line: Growth responsiveness and induction of colony-stimulating factor. J. Cell. Physiol., 114: 291-301. 
15. OHKI, K. and Nagayama, A. 1988. Establishment and characterization of factor-dependent macrophage cell lines. J. Leukocyte Biol., 44: 465-473.

16. OhKi, K., Soljima, T., Kohashi, O., and Nagayama, A. 1991. Opposite effects of bacterial lipopolysaccharide on Fcreceptor-mediated phagocytosis of two bone marrow-derived macrophage cell lines, BDM-1 and BDM-1W3. Cell Struct. Funct., 16: 495-502.

17. Ohki, K., NagaYama, A., and Kohashi, O. 1992. Differential effects of bacterial lipopolysaccharide and interferon- $\gamma$ on proliferation of two factor-dependent macrophage cell lines. Cell Struct. Funct., 17: 161-167.

18. SAWYER, R.T. 1986. The significance of local resident pulmonary alveolar macrophage proliferation to population renewal. J. Leukocyte Biol., 39: 77-87.

19. Schumann, R.R., Leong, G.W., Flaggs, P.W., Gray, S.D., Wright, J.C., Mathison, P.S., Tobias, P.S., and UleVitCh, R.J. 1990. Structure and function of lipopolysaccharide binding protein. Science, 249: 1429-1431.

20. Stanley, E.R. 1986. Action of the colony-stimulating factor, CSF-1. Ciba Found. Symp., 118: 29.

21. Streilein, J.S. and Hart, D.A. 1978. Role of alpha globulins in nonspecific regulation of the immune response: Possible mechanisms for external and internal signals. Federation Proc., 37: 2042-2044.

22. Ulevitch, R.J. and Johnson, A.R. 1978. The modification of biophysical and endotoxic properties of bacterial lipopolysaccharides by serum. J. Clin. Invest., 62: 1313-1324.

23. Ulevitch, R.J., Johnston, A.R., and Weinstern, D.B. 1979. New function for high density lipoproteins. Their participation in intravascular reactions of bacterial lipopolysaccharides. J. Clin. Invest., 64: 1516-1524.
24. Ulevitch, R.J., Johnston, A.R., and Weinstein, D.B. 1981. New function for high density lipoproteins. Isolation and characterization of a bacterial lipopolysaccharide-high density lipoprotein complex formed in rabbit plasma. J. Clin. Invest., 67: 827-837.

25. Vairo, G., Argyriou, S., Knight, K.R., and Hamilton, J.A. 1991. Inhibition of colony-stimulating factor-stimulated macrophage proliferation by tumor necrosis factor- $\alpha$, IFN- $\gamma$, and lipopolysaccharide is not due to a general loss of responsiveness to growth factor. J. Immunol., 146: 3469-3477.

26. VAN FURTh, R. and DeN DUlK, M.M.C.D. 1984. Dual origin of mouse spleen macrophages. J. Exp. Med., 160: 1273-1283.

27. van Lenten, B.J., Fogelman, A.M., Haberland, M.E., and EDWARDS, P.A. 1986. The role of lipoproteins and receptormediated endocytosis in the transport of bacterial lipopolysaccharide. Proc. Natl. Acad. Sci. USA, 83: 2704-2708.

28. Walker, S.M., Sturtevant, J.E., and Weigel, W.O. 1981. Serum-mediated suppression of nonspecific B cell activation. I. Description of an inhibitory capacity in normal mouse serum and characterization of the inhibitory component. J. Immunol., 126: 1852-1856.

29. Wright, S.D., Ramos, R.A., Tobias, P.S., Ulevitch, R.J., and MAthison, J.C. 1990. CD14, a receptor for complexes of lipopolysaccharide (LPS) and LPS binding protein. Science, 249: 1431-1433.

30. YEN, S.-E. and Stewart, C.C. 1982. Effects of serum fractions on the growth of mononuclear phagocytes. J. Cell. Physiol., 112: 107-114.

(Received for publication, May 18, 1993

and in revised form, August 1, 1993) 